University at Albany, State University of New York

Scholars Archive

2013

\title{
Teachers' and Administrators' Use of Evidence of Student Learning to Take Action: Conclusions Drawn from a Special Issue on Formative Assessment
}

\author{
Heidi Andrade \\ University at Albany, State University of New York, handrade@albany.edu \\ M. Christina Schneider \\ McGraw-Hill
}

Follow this and additional works at: https://scholarsarchive.library.albany.edu/etap_fac_scholar

Part of the Education Commons

\section{Recommended Citation}

Andrade, Heidi and Schneider, M. Christina, "Teachers' and Administrators' Use of Evidence of Student Learning to Take Action: Conclusions Drawn from a Special Issue on Formative Assessment" (2013). Educational Theory and Practice Faculty Scholarship. 11. https://scholarsarchive.library.albany.edu/etap_fac_scholar/11

This Article is brought to you for free and open access by the Educational Theory and Practice at Scholars Archive. It has been accepted for inclusion in Educational Theory and Practice Faculty Scholarship by an authorized administrator of Scholars Archive. For more information, please contact scholarsarchive@albany.edu. 


\title{
GUEST EDITORS’ INTRODUCTION
}

\section{Teachers’ and Administrators’ Use of Evidence of Student Learning to Take Action: Conclusions Drawn from a Special Issue on Formative Assessment}

\author{
M. Christina Schneider \\ СТВ McGraw-Hill \\ Heidi Andrade \\ University at Albany-SUNY
}

\begin{abstract}
A teacher who collects and analyzes diverse types of evidence of a student's learning and uses that information to either adjust instruction or provide feedback to the student is using formative classroom assessment (Brookhart, Moss, \& Long, 2008). A central feature of formative assessment is a clear link between the results of an assessment and subsequent actions that lead to gains in student learning (Nichols, Meyers, \& Burling, 2009; Wiliam, 2010). The impact of formative assessment is greatly diminished if teachers are not able to use evidence of student learning to determine next instructional steps and help students move their own learning forward (Heritage, Kim, Vendlinski, \& Herman, 2009). Until recently, however, there has been little research on how often and how well teachers use formative assessment practices in the classroom-hence the theme of this issue. The findings from this set of articles, which investigate teacher and administrator formative practices at different levels of granularity and using different measures, address the following questions:

- How well do teachers use formative assessment practices?

- Do most teachers have sufficient skill to analyze student work?

- How do teachers use evidence of student learning to adapt instruction on the intended learning target?

- What professional development and instructional material supports are necessary to help teachers improve their formative assessment practice?
\end{abstract}




\section{THE GOOD NEWS}

Some of the findings reported in this issue show the benefits of engaging in formative practices. Among the bright spots are the student-teacher teamwork that is observed in the classroom studied by Heritage and Heritage (this issue), as well as the ways in which the teacher was able to individualize instruction based on informal, formative assessment information. Heritage and Heritage note that open, respectful teacher questioning is essential to elicit students' present level of performance and guide decisions about next steps.

Moss, Brookhart, and Long (this issue) also provide encouraging news of administrators who are highly engaged in supporting their teachers in using formative assessment. The highly engaged administrators established teacher learning communities that focused on evidence of student learning rather than on teacher-led instructional activities. The teachers most skilled in formative assessment practices shared learning targets and success criteria with students multiple times and in a variety of ways.

\section{THE BAD NEWS}

The research reported in this issue also raises concerns regarding whether most teachers engage in frequent and effective formative assessment practices. Taken together, several of the studies suggest that teachers do not have clearly articulated learning targets, have difficulty interpreting assessment information, provide infrequent and uninformative feedback to students, and make formative use of summative assessment data in only cursory ways. For example, Moss, Brookhart, and Long (this issue) found through data collected by school administrators that some teachers had not defined learning targets on which to center their own instructional planning. The teachers who were identified as struggling teachers did not have clear lesson objectives or criteria and, as a result, they could not communicate their expectations to students. In these classrooms, $50 \%$ of the observed student work showed minimal connection to learning targets.

The studies in this special issue suggest that many teachers struggle to both interpret evidence of student learning from formative assessment processes and provide students with feedback that moves learning forward. Examining science journals, Ruiz-Primo and $\mathrm{Li}$ (this issue) found that on average teachers provided about two pieces of written feedback per student on a science unit. However, $61 \%$ of the feedback pieces were grades, numbers, or symbols, and only $33 \%$ were narrative comments. Only $14 \%$ of the feedback comments met the authors' criteria for having the potential to move student learning forward. Another way to think of these findings is that if such a teacher was consistent in providing feedback across students and assignments, a student would find written teacher feedback helpful for figuring out what to do next on one or two assignments out of 10. Depending upon the frequency of assignments, this could mean that students were getting helpful information once every 2 weeks or possibly only once in a grading period.

Schneider and Gowan (this issue) found that teachers found it relatively more difficult to provide feedback to move students forward than to determine what an item measures, interpret a student's response to an item, or set next instructional steps. Schneider and Gowan conjectured that the low quality of feedback found in their study was attributable to the teachers' general inability to analyze the cause of student confusion. Teachers tended to take a one-size-fits-all 
Approach when determining what instructional adaptations to make or feedback to provide to a student based on the student's response. This finding supports Schneider and Meyer's (2012) belief that teachers may not be directing re-teaching specifically to where the student is in a learning progression, which may hinder student achievement.

When analyzing teacher self-reported data about how they use various types of summative data in a formative manner, Hoover and Abrams (this issue) found that only about $30 \%$ of teachers engaged in an item-level analysis of test results on a weekly basis, and $64 \%$ of the teachers reported that instructional pacing prohibited re-teaching of concepts. They also found that teachers may be simply using the average score on an assessment as their main investigational focus when looking at such assessment data. Although this data point might be useful for determining whether the average student in the class is ready to move on or is on track to meet state proficiency targets, it provides neither the teacher nor the student sufficient depth of information to diagnose gaps, confusions, or strengths in individual student's thinking.

\section{IMPLICATIONS FOR PROFESSIONAL DEVELOPMENT AND RESEARCH}

The bulk of the findings reported in this issue are distressing but unsurprising, given inadequate assessment-related preparation and professional development provided to teachers (Popham, 2009). Part of the value of the studies in this issue is the implication for professional development and research that can be drawn.

The good news suggests that effective formative assessment is possible, under the right conditions. The bad news suggests that teachers need support in (a) designing instructional sequences based on state standards, (b) effectively engaging in formative assessment practices, and (c) moving beyond a one-size-fits-all approach to reteaching concepts. The latter two items also require that teachers develop skills related to interpreting evidence of student learning, and in targeting feedback and instructional adaptations directly to a student's present level of performance.

Moss, Brookhart, and Long (this issue) provide evidence that teachers (and administrators) have different professional development needs; yet, they too are often provided a generic onesize-fits-all approach. Researchers need to determine the learning trajectory for being an efficient, effective user of formative assessment that can inform pre- and in service support based on individualized needs. Of course, teachers and administrators must also have the sanctity of professional development time to achieve these goals.

The components of the formative assessment proficiency trajectory that should be targeted by preservice institutions, by the districts, and the optimal amount of overlap is another area in need of study. Given that the skills needed by teachers and administrators to be efficient, effective users and leaders of formative assessment are complex and likely require years of practice to acquire, what supports should be provided in the interim? Preservice institutions, district administrators, and state departments of education should collaborate to map a sustained, sequential, adaptive, and individualized series of integrated professional development programs, as well as evaluations of their effectiveness so that they can be improved over time. Publishers might consider creating instructional and test reporting materials that make the work of diagnosing student instructional needs easier and less time consuming. Examples of student work that exemplify where a student is located within a learning progression or that are associated with common misconceptions could 
Be provided, along with recommended next instructional steps. In order to achieve the desired increases in student achievement to which we all aspire, the education community must be just as nimble in supporting teacher learning as we expect teachers to be in supporting student learning and administrators to be in supporting teacher learning.

\section{REFERENCES}

Brookhart, S. M., Moss, C. M., \& Long, B. A. (2008, March). Professional development in formative assessment: Effects on teacher and student learning. Paper presented at the meeting of the National Council on Measurement in Education, New York, NY.

Heritage, M., Kim, J., Vendlinski, T., \& Herman, J. (2009). From evidence to action: A seamless process in formative classroom assessment? Educational Measurement: Issues and Practice 28(3), 24-31.

Nichols, P. D., Meyers, J. L., \& Burling, K. S. (2009). A framework for evaluating and planning assessments intended to improve student achievement. Educational Measurement: Issues and Practice, 28(3), 14-33.

Popham, J. (2009). Assessment literacy for teachers: Faddish or fundamental? Theory into Practice, 48(1), 4-11.

Schneider, M. C., \& Meyer, J. P. (2012). Investigating the efficacy of a professional development program in formative classroom assessment in middle school English language arts and mathematics. Journal of Multidisciplinary Evaluation 8(17), 1-24.

Wiliam, D. (2010). An integrative summary of the research literature and implications for a new theory of formative assessment. In H. Andrade, \& G. Cizek (Eds.), Handbook of formative assessment (pp. 18-40). New York, NY: Routledge. 